\title{
Factors influencing management development of MBA students: Exploring concerns of business schools in Pakistan
}

Obed Rashdi Syed

Universiti Teknologi Malaysia

Rosmini Omar

Universiti Teknologi Malaysia

Arabella Bhutto

Mehran University of Engineering and Technology

\section{Recommended Citation}

Syed, O. R., Omar, R., \& Bhutto, A. (2018). Factors influencing management development of MBA students:

Exploring concerns of business schools in Pakistan. International Interdisciplinary Business-Economics

Advancement Journal, 3(1), 1-18.

\section{Revisions}

Submission date: Feb. 17, 2017

1st Revision: Apr. 5, 2017

2nd Revision: Jun. 29, 2017

Acceptance: Jul. 15, 2017 


\title{
Factors Influencing Management Development of MBA Students: Exploring Concerns of Business Schools in Pakistan
}

\author{
Obed Rashdi Syed ${ }^{1}$, Rosmini Omar ${ }^{2}$, and Arabella Bhutto ${ }^{3}$ \\ Azman Hashim International Business School \\ Universiti Teknologi Malaysia, Malaysia \\ 1obedrashdi@ibs.utm.my \\ ${ }^{2}$ rosmini@ibs.utm.my
}

Institute of Science, Technology and Development

Mehran University of Engineering and Technology, Pakistan

${ }^{3}$ rbll_bhutto@yahoo.com

\begin{abstract}
The purpose of this study is to explore factors that reinforce or obstruct business schools in Pakistan to develop managerial knowledge, skills and work-based learning experiences of MBA students. The study is prompted by growing debates about insufficiencies in business schools to prepare MBA graduates based on managerial capital needs in the regional markets. To understand the reasons of insufficiencies from business school's viewpoint, this study employs qualitative interviews to explore factors that reinforce or obstruct business schools. Deans, faculty members and administrators of five different business schools in Hyderabad, Pakistan participated in this study. Responses of the participants are transcribed into verbatim reports and description of findings is structured in SWOT analysis format. Findings show sixteen different factors, comprising of four strengths, seven weaknesses, three opportunities, and two threats. There are more number of weaknesses of business schools to develop MBA students. However, business schools have some strengths and opportunities which they may utilize and improve. Radical changes would strive from the higher education authority. Conceptual framework presented in this study recommends that higher education authority may lead the change, cooperate between business schools and stakeholders, and support business schools to develop future managers and leaders through MBA programs.
\end{abstract}

Keywords: management development, MBA, business schools, SWOT analysis

\section{Introduction}

Business schools have enjoyed exclusive status in academic markets and have successful stories in higher education sector since last few decades. Master of Business Administration (MBA) in particular is considered as an elite management education program because of its value in employer organizations and preference by many business students (Baruch, 2009; Pimpa, 2009). However, recent authors (Datar, Garvin, \& Cullen, 2011; Harrington \& Kearney, 2011; Hommel \& Thomas, 2014; Jamil, 2015; Mitroff, Alpaslan, \& O' Connor, 2015; Muff, 2012) highlight 
some disappointments and assert that business schools are deviating from their primary purpose of professionalizing the business community (Khurana, 2010) and at the same time business schools are not properly serving their stakeholders (Thomas, Thomas, \& Wilson, 2013). In addition, business schools have been neglecting public and environmental interests in management education programs, causing business schools and management education being partially responsible for the Global Financial Crisis of 2008 (Muff et al., 2013; Örtenblad, Koris, Farquharson, \& Hsu, 2013).

Management education programs and theories are typically inconsistent and propagating management practices other than the real organizations. Cunliffe (2014), Ghoshal (2005), Locke and Spender (2011) and Wright, Paroutis, and Blettner (2013), for instance, base their studies on the argument that business schools are rather going against actual management practices. Numerical modellings and irrelevant concepts offered by business schools are causing organizations to ignore management education programs, because graduates are incapable to wrangle with real organizational problems and lead people (Kieser \& Leiner, 2009). In addition, many business schools have weak ties with stakeholders and remain unfamiliar about actual needs and expectations of businesses and students (Sambrook \& Willmott, 2014; Syed \& Omar, 2016; Thomas et al., 2013). Yet, business schools continue to overemphasize traditional and analytical academic practices which further increases the mismatch between supply of graduates from business schools and actual managerial capital needs of organizations.

The debate on insufficiencies in business schools in the management literature is growing and theorists are primarily discussing problems versus solutions in the context of industrialized and developed nations. Comparatively less focus has been paid to disclose similar or additional concerns of business schools and deficiencies in MBA programs in the developing countries context (Jamil, 2015; Ly, Vickers \& Fernandez, 2015; Maddison, 2013; Saks, Tamkin, \& Lewis, 2011). In fact, there is massive shortage of managerial capital in the developing nations (Nabi \& Liñán, 2011) and business schools being academic institutions have opportunities to overcome those insufficiencies (Paton, Chia, \& Burt, 2014). Yet, the issue of irrelevance still exists. Therefore, this paper attempts to study business schools in an Asian developing country Pakistan.

The general scenario of Pakistan is quite perplexing and contradictory to many other Asian countries. Regardless of having tremendous natural and human resources within its territory, the country is facing several challenges concerning to growing urbanization (Mustafa \& Sawas, 2013), religious ideologies and geopolitical foreign interferences (Blank, Clary, \& Nichiporuk, 2014), social instability, terrorism and insecurity issues (Khan, Estrada, \& Yusof, 2015), which collectively cause economic and social downfalls. On the other hand, the country has numerous family-owned businesses and corporate level industries that demand strong internal and external corporate governance mechanisms to support their capital structures (Sheikh \& Wang, 2012). Therefore, the country needs proper development of managerial capital in business schools to reinforce the economy and social developments. To explore concerns of business schools in Pakistan regarding management development of students in MBA programs, we base this study on the following question: What factors influence management development of MBA students in business schools in Pakistan? 


\section{Management Development in MBA}

Wexley and Baldwin (1986) identified three components that are potentially important inputs for management development of individuals, namely, management education, management training, and on-the-job experience. "Management education denotes those activities traditionally conducted by colleges and universities that focus on developing a broad range of managerial knowledge and general conceptual abilities" (Wexley \& Baldwin, 1986, p. 278). Management training "covers those activities designed to impart specific managerial skills which would be immediately applicable in a particular organizational setting" (Wexley \& Baldwin, 1986, p. 280). And, on-the-job experience is a situation in which individuals learn by performing managerial tasks and undertakings, for instance, "managers in unfamiliar jobs and/or unfamiliar settings" and where "mentoring is a critical on-the-job management development tool" (Wexley \& Baldwin, 1986, pp. 285-286).

According to Wexley and Baldwin (1986), management education actually refers to the development of managerial knowledge through conceptual and theory-based academic courses; management training is to develop managerial skills through training contents and methods; and on-the-job experience is work-based learning in physical organizations.

\section{Management Education}

In the literature on organizational management, two forms of knowledge are mainly discussed, namely, tacit and explicit (Nonaka \& Takeuchi, 1995). Gera (2012) defines tacit knowledge as procedural and experiential knowledge that exists within individuals, for instance, business managers and faculty members in management education context. Explicit knowledge is codified and formalized knowledge, for instance, published research articles, books and operating documents like case studies and training manuals, which are readily available for learning managerial procedures or methods. According to Meyer (2003), tacit knowledge is the knowledge of "know-how" and explicit is the knowledge of "know-what" (p. 461), and the knowledge of know-how has strategic importance in business organizations. Meyer (2003) also discusses about the value of knowledge-in-action in organizations, which he defines as "collective experience of the members of a community of practice which is surfaced by peer practitioners as they engage in problem-focused dialogue" (Meyer, 2003, p. 462). Dialogue in here refers to exchange of ideas or opinions.

So far in management education context, knowledge about business enterprises, management tools and techniques are transmitted through different books and courses which offer students a rich and relevant explicit knowledge. Transmitting tacit knowledge and knowledge-in-action to MBA students is a challenging task (Fincham \& Clark, 2009). However, business schools frequently updating their MBA course contents and co-curricular activities through dialogue with practitioners could overcome the challenge (Meyer, 2003).

\section{Management Training}

Managerial skills of students can possibly develop through management training in MBA programs. Varela, Burke, and Michel (2013) have discussed two types of managerial skills that are necessary to be developed through MBA programs, namely, soft and complex managerial 
skills. Soft skills are functional skills, personal skills and interpersonal skills which are delivered through MBA co-curricular activities. Complex managerial skills are human interactive and competency-based skills which remain a challenge for business schools. Varela et al. (2013) argued that complex managerial skills can be learned through life-long learning process, however, business schools are confronted by time limitations, contextualized learning, constraints to testing new knowledge, and limited feedback opportunities.

Some business schools have greatly responded to these limitations through different innovations in MBA programs (Datar et al., 2011). However, those innovations are mainly found in top business schools, whereas majority of business schools especially in developing countries are still unable to follow-up practices led by the bellwethers of management education. In addition, many Asian academic institutions try to replicate management education curriculum and cocurricular activities developed for the Western and developed nations (Waterval, Frambach, Driessen, \& Scherpbier, 2015), which does not necessarily develop MBA graduates to match with the needs of regional businesses (Pimpa, 2009). Perhaps business schools could first identify needs and expectations of regional employers of MBA graduates and then review and adapt MBA education model that reinforces the growth of regional businesses.

\section{On-the-job Experience}

On-the-job experience is a work-based learning experience (Wexley \& Baldwin, 1986). Business schools are using multiple methods to develop knowledge and skills of MBA students through lecture classes and seminars, sharing of knowledge from books and articles, engaging students in co-curricular activities, project assignments, case-methods, research undertakings, and enabling in-class interaction with managers and entrepreneurs (Datar et al., 2011; Paton et al., 2014; Posner, 2009). However, work-based learning experience is more practical approach than abovementioned. According to Wexley and Baldwin (1986), on-the-job experience places the individual in the chair of manager to deal with real people and problems in the organization and execute decisions under limited time, resources and other issues.

Work-based learning experience is similar to the concept of action learning (Revans, 1982). According to Revans (1998), "there can be no action without learning, and no learning without action" (p. 83). Business schools offer internship opportunities and research projects in MBA programs to develop managerial experiences of MBA students. However, these short-tenured trainings do not necessarily prepare graduates to manage businesses and lead people in real organizations. Work-based learning experiences could possibly be effective when the mentorship is led by business school faculty members having industrial background. For this purpose, it is necessary for business schools to grow collaborations with local businesses and industry players.

\section{Summing up}

All three components of management development, namely, management education, management training and on-the-job experience are important for preparing MBA students for future managerial positions. Several recent authors have studied business schools (Harrington \& Kearney, 2011; Hommel \& Thomas, 2014; Mitroff et al., 2015; Paton et al., 2014; Syed \& Omar, 2016), MBA programs (Baruch, 2009; Datar et al., 2011; Jamil, 2015; Varela et al., 2013) and development of students in business schools (Khurana, 2010; Muff et al., 2013; Örtenblad et al., 
2013) from different perspectives. However, collective development of complex managerial skills, critical self-reflection on action learning and specifically offering work-based learning experiences to MBA students in organizations remain an emergent area of study. In addition, factors that influence development of MBA student's knowledge, skills and experiences differ in accordance to contextual, social and environmental setting of the business school. Therefore, this study intends to explore business schools in one of the wealthy cities of Pakistan - Hyderabad to uncover concerns of business schools regarding management development of MBA students.

\section{Business Schools in Pakistan}

Higher Education Commission (HEC), founded in 2002 as University Grant Commission, is the regulatory body of higher education in Pakistan. The HEC issues list of recognized academic institutions, degree programs and regulates admission procedures, courses and faculty selection criteria in the country. There are approximately 99 university departments and standalone business schools in Pakistan (AACSB, 2015).

Institute of Business Administration (IBA) is the first public business school to offer bachelors and masters level degree programs in business administration in the country (Khan, Shah, \& Azam, 2011). IBA was established in 1955 with procedural support by Wharton School of Finance, Pennsylvania University in the US. Lahore University of Management Sciences (LUMS) is the first private business school in Pakistan. LUMS was established in 1986 and emerged as one of most competent business schools in the country (Kaleem, 2005). Both these institutions are leading business schools in the country because of their strong foundation and continuous growth.

\section{Business Schools in Hyderabad}

Hyderabad city is one of oldest urban cities of Asia situated in Sindh province of Pakistan. Hyderabad connects the metropolis city of Karachi with vast populace of other urban and rural areas of Sindh. The city provides numerous opportunities to the region in terms of education, agriculture markets, natural resources, and comprises of many family-owned businesses, and textile, banking and trade industries (Ali, 2011; Ismail, Anjum, Mamon, \& Kazi, 2011; Mari, Shahzadi, \& Chachar, 2011; Rahman, 1999). Hyderabad also possesses some of the largest and renowned academic institutions of Sindh province within its territory, namely, University of Sindh, Mehran University of Engineering and Technology, Liaquat University of Medical and Health Sciences, ISRA University and many other private and affiliated university colleges. In sum, the city is very resourceful and has great prospects of developments, which may also assist overcoming several developmental deficiencies in surrounding urban and rural areas.

There are nine business schools recognized by the HEC that offer on-campus MBA programs in Hyderabad. Out of the total, three business schools are management sciences departments of degree awarding public universities, and two business schools are management sciences departments of private universities. In addition, there are four private colleges affiliated with public universities also offering on-campus MBA programs. In total, this study has found three public and six private business schools in Hyderabad. 
For this study, five business schools have been selected. The selection is based on reputation of business schools in the academic market, preference of students for MBA education, and maturity of business schools in terms of offering MBA programs in Hyderabad. Participants have recommended to represent their schools anonymously, therefore, the names of business schools are codified. Table 1 lists selected business schools with their basic characteristics.

Table 1: Selected Business Schools, Basic Characteristics and Age of Business Schools

\begin{tabular}{lllc}
\hline & \multicolumn{1}{c}{ Name } & \multicolumn{1}{c}{ Basic Characteristic } & Age of Business Schools \\
\hline 1 & Alpha Business School (ABS) & $\begin{array}{l}\text { Faculty of public and degree } \\
\text { awarding university }\end{array}$ & $>30$ years \\
2 & Beta Business School (BBS) & $\begin{array}{l}\text { Faculty of private and degree } \\
\text { awarding university }\end{array}$ & $>15$ years \\
3 & Gamma Business School (GBS) & $\begin{array}{l}\text { Faculty of private and degree } \\
\text { awarding university }\end{array}$ & $>5$ years \\
4 & Delta Business School (DBS) & $\begin{array}{l}\text { Private institution, affiliated with } \\
\text { local public universities } \\
\text { Private institution, affiliated with } \\
\text { local public universities }\end{array}$ & $>15$ years \\
\hline
\end{tabular}

\section{Research Methodology}

This study intends to identify factors that influence business schools' endeavors of developing managerial knowledge, skills and work-based learning experiences of students in MBA programs. For this purpose and in accordance to the question of inquiry, qualitative research method is suitable for this study (Creswell, 2012). Qualitative research enables to inquire about meaning and understanding ascribed to social and human problems and concerns in the real-life environment. This characteristic of qualitative research favors the objectives of this study - to explore the viewpoint of individuals in business schools about the phenomenon and at their real workplace (Creswell, 2012; Leedy \& Ormrod, 2001).

Qualitative research is an in-depth exploration and typically the sample size tends to be smaller than the sample size in quantitative research study (Miles, Huberman, \& Saldana, 2014). Findings of qualitative research are context specific and less concerned about issue like generalizability. Accordingly, the study selects five business schools in Hyderabad and uses snowball sampling strategy to select participants for the interviews. The study uses combination of exploratory, interpretative and descriptive approaches to explore and describe the understanding and opinions of participants in business schools regarding management development of MBA students. The data analysis is based on verbatim reports which were transcribed manually to develop and classify themes based on specified components of SWOT analysis for data summarization, data display and derive conclusions.

\section{Questions Asked From the Participants}

Interview questions are open-ended and interactive to obtain required information. Participants were first asked to share basic information about their business schools, MBA programs, faculty members and MBA students. Participants were then asked to answer and discuss, but certainly not limited to, the following questions: 
Factor influencing management development of MBA students (in SWOT analysis format):

- Factors influencing development of managerial knowledge (tacit knowledge and knowledge-in-action).

- Factors influencing development of managerial skills (soft and complex managerial skills).

- Factors influencing development of managerial experiences (work-based learning).

The strategic management tool of SWOT analysis has helped the participants of this study to specify and explain factors that influence management development of MBA students in business schools. The 'strength' segment specifies strong points that support management development of MBA students; 'weakness' segment highlights drawbacks of business schools towards the same aim. The segment of 'opportunity' discovers some external supporting factors available for business schools to utilize; and 'threat' segment identifies external pressures that hinder business school's aim of developing managerial knowledge, skills and work-based learning experiences of MBA students.

\section{Data Collection}

We first reached the heads of business schools - deans and chairmen via telephone and face-toface meetings for the interview appointments. After interviewing them, they were asked to identify next key person to further elaborate on the questions being asked, be it faculty members and administrators in that particular business school. Similar practices of interviews were followed in all five business schools. Table 2 lists number of participants interviewed in each business school.

Table 2: Number of Participants in Selected Business Schools

\begin{tabular}{llc}
\hline Names of Business Schools & $\begin{array}{l}\text { Participants and their } \\
\text { Positions in the School }\end{array}$ & $\begin{array}{c}\text { Number of } \\
\text { Participants }\end{array}$ \\
\hline Alpha Business School (ABS) & 1 Head (DN) & 5 \\
& 1 Associate Professor (AP) & \\
& 1 Senior Lecturer (SL) & \\
& 1 Lecturer (LR) & \\
& 1 Administrator (AD) & \\
\hline Beta Business School (BBS) & 1 Head (DN) & \\
& 2 Senior Lecturers (SL) & \\
& 1 Lecturers (LR) & \\
\hline Gamma Business School (GBS) & 1 Head (DR) & 3 \\
& 1 Senior Lecturer (SL) & \\
\hline Delta Business School (DBS) & 1 Administrator (AD) & \\
& 1 Head (CI) & \\
& 1 Lecturers (LR) & \\
\hline Epsilon Business School (EBS) & 1 Administrator (AD) & \\
& 1 Head (CH) & \\
\hline Total & 1 Deputy head (PP) & \\
\hline
\end{tabular}

There are total eighteen research participants in this study. Twelve interview sessions are conducted with individual participants and three interview sessions are conducted with two 
participants in a group. Individual interviews are conducted with faculty members and administrators, whereas three heads of business schools were accompanied with faculty members who deal with MBA programs and co-curricular activities. ABS, BBS and GBS are degree awarding institutions and they have their own teaching staff and few visiting faculty members. Whereas DBS and EBS, alike many other private affiliated colleges in Hyderabad, have several visiting faculty members from local colleges and universities.

Each interview took about 40-50 minutes of time. Responses of participants are recorded and captured in audio files. Few participants disagreed to have their voices recorded; therefore, handnotes are taken during the interview. Each participant has highlighted positive as well as negative aspects of their respective business schools regarding management development of MBA students. Findings are descriptively presented in the following sections.

\section{Description of Findings}

Description of collective notes are compiled, manually transcribed into verbatim reports and classified into strengths, weaknesses, opportunities and threats (SWOT) format. Each segment of SWOT is elaborative with responses of participants in the following sections.

Strengths of Business Schools to Develop MBA Students:

Strength 1: Initiatives and efforts of faculty members and head of business school at personal level

Degree awarding institutions have more resources and connections than affiliated academic institutions. Therefore, individual initiatives at personal levels are more achievable in degree awarding institutions. An AD at ABS states that “...our institute is old and famous... we have lot of connections". Private university business schools also utilize personal contacts. SL at BBS notifies that they interact with managers because it "...enables exchange of knowledge...students learn from (manager's) experiences". In addition, SL at BBS also says that their teamwork with organizations “...provides internship opportunities to our students". Whosoever realize these benefits use their personal efforts to bring knowledge from practitioners they know in personal capacity. DR at GBS notifies that they also "...invite foreigners to visit and share knowledge" with their school. These activities help and encourage business schools to develop MBA students.

\section{Strength 2: Contributions of fresh and foreign qualified faculty members}

The DR and AD at GBS claim that they only appoint foreign qualified job candidates as permanent faculty members in their school, because these individuals are more "...knowledgeable and exposed to a developed society...contribution is much better than local (qualified) faculty" (DR at GBS). Similar observations are made by APs at ABS and BBS while sharing their experiences of education abroad. "We learned a lot...they keep students busy with different tasks...I share my experiences (with students) so they can learn how people work there" (AP at ABS). "I personally would say that results are huge...we met good academicians, conducted research, learned research methods, and experienced seminars" (AP at BBS). Thus, foreign qualified faculty members perform better because they are well-educated and knowledgeable. 


\section{Strength 3: Role of Students with management education background}

Enrolment of students in institutions play a crucial role in educating future business managers and leaders. Students having bachelor degrees in business administration are "...active and productive" (LR at BBS) and they "...complete assignments... and they are thought provoking" (SL at GBS). CI at DBS shares similar concerns of faculty members saying that "...students with $B B A$ (Bachelor of Business Administration degree) perform better than non-BBA students (translated into English)". Therefore, students having prior degrees in business learn fast and produce better results than students having prior degrees in other fields, and these students motivate faculty members as well.

\section{Strength 4: Working students (managers and entrepreneurs)}

At ABS, DBS and EBS, working-adults are, however, also enrolled as fulltime students in evening or weekend MBA programs. These students are comparatively better learners and performers than many other fulltime students. Students who are practitioners "... are mature and well-learned...their response is productive" (LR at ABS). With this awareness, we questioned participants at DBS and EBS about contributions of working MBA students. Two faculty members we interviewed at DBS and EBS agree and support this statement that engaging with working-students enhance their and other students' knowledge.

Weaknesses of Business Schools to Develop MBA Students

Weakness 1: Lack of faculty members' interests and capabilities

Some faculty members who are permanently employed also teach at other private institutions for financial reasons, rather than enhancing the quality of education at their institutions (DN at $\mathrm{ABS}$; $\mathrm{AD}$ at DBS; PP at EBS). Heads of $\mathrm{ABS}$ and GBS believe that they cannot restrain faculty members from teaching at other institutions or from sharing their expertise. However, GBS encourages their faculty members through tours and visits to different industries and academic institutions to keep them motivated towards their institution. BBS has "...in-house training center... (and) performance appraisal of HR department (which) define areas of improvements" (DN at BBS). Participants in both these schools believe that these activities encourage their faculty members to stay committed with their school.

\section{Weakness 2: Politics in academia}

Appointment of new faculty member or administrator in a vacant position grasps attention of political and social forces (AD at ABS; AD at DBS). Few faculty members shared their personal dissatisfactions with political involvement in their academic institutions saying that, promotions in grade, foreign and national visits, financial increments and many other benefits are driven by personal interests of department heads or by some political pressures. In public universities, “...comrades (political activists/students) force teachers to shutdown classes...typically happening in every semester... (this issue) devalue teachers and hurt our self-respect" (LR at ABS). Participants in BBS and GBS did not share anything related to internal politics in their school, however, they agree that there are some administrative limitations and external political and social influences which hurdle some academic endeavors. 
Weakness 3: Low fee structure of MBA programs

Low fees structure of MBA programs eventually reduces the overall quality of the education (LR and $\mathrm{AD}$ at ABS; $\mathrm{AD}$ at DBS). At BBS and GBS, MBA fees annually is almost double than the fees at ABS, DBS and EBS. PP of EBS says that it is their vision "...to provide quality education at affordable cost". At BBS and GBS, quality of education, performance of faculty members and developments of MBA students is relatively better than the other schools. Income generated through MBA enables the schools to offer better educational experiences and attract and retain competent faculty members.

\section{Weakness 4: Lack of student's interests}

Participants connect performance of students with local environment of business schools and Hyderabad city, saying that students have tendency to skip academic workloads, assignments and presentations (SL at ABS; CI at DBS; SL at EBS). AD at GBS highlights that their school environment is very friendly yet strictly disciplined. DN and SL at BBS point out two things that balance their relationship with students: "...motivation by staff" and "...fear of rules and regulations". Many MBA students in private, affiliated institutions are working-adults. These students "...never complete assignments on time... sleep in class...do MBA to get promotion" (SL at EBS). It shows that lack of students to understand and actively participate in undertakings related to management development remains a challenge for business schools.

\section{Weakness 5: Shortage of local-business based literature, research and case-studies}

Faculty members notified about shortage of literature and publications on local industry. Business schools "...use HEC (designed) curricula...based on that students are taught and examined" (SL at ABS). Even business schools "...do not have our (locally made) case studies...(rather) buy from Harvard" (LR at BBS). DR at GBS in this context expresses his concerns that "We don't have research environment", and therefore they "...use foreign books (by foreign authors)", including case studies and other activities (SL at GBS). LR at DBS and SL at EBS told that it is their school to provide them topics to teach every semester. These faculty members "...take classes regularly and complete courses on time... and rush to other institution for another class (translated into English)" (AD at DBS). With these limitations, motives and schedules, many faculty members hardly get inclined to do research and produce publications on local industry.

\section{Weakness 6: Inadequate educational background of students}

Business schools in Hyderabad require students to have bachelor degrees in any discipline to become eligible for the admission in MBA programs. Combination of students with different educational backgrounds and knowledge in MBA class create challenges for faculty members. $\mathrm{AD}$ at GBS shares concern of faculty members saying that "Our teachers put more efforts on students without BBA". SL at ABS says the same, "...there is problem with college-side students...they have no background knowledge of business...(and) have low moral values". These students “...bunk classes...don't complete assignments...(and) copy paste material from internet" (LR at DBS). Every faculty participant points-out issue of prior education of students in MBA programs. 


\section{Weakness 7: Overpopulated MBA students in classrooms}

Number of students in MBA classrooms in BBS and EBS are between 25-35. MBA students in DBS and GBS classrooms range from 15-30 students. However, MBA classrooms in ABS are overpopulated with more than 100 students. LR at ABS says "...there is no fixed number of students...some students are (enrolled through) merit and some are self-financed". SL at ABS says that "...huge number of students do not create rich learning environment in class...teacher can't remember names...impossible for teachers to read, mark and discuss work with students". Participants at BBS, GBS, DBS and EBS are satisfied with the number of students in classrooms and recommend to not increase the number of students.

\section{Opportunities for Business Schools to Develop MBA Students}

\section{Opportunity 1: Benefits for faculty members and local managers}

Financial benefits and career advancements may encourage faculty members and local practitioners to cooperate and contribute in developing MBA students. AD of DBS says that "...our old teachers who have been teaching same subjects for years have same things in their minds...they do not update their knowledge (translated into English)". AP at ABS says that "If a professor invest more time to develop competency of students, he has to work hard...he should get incentives for extra efforts". SL at GBS says that "I have seven assignments in the university... and they pay nominal salary". When we questioned about additional benefits for faculty members to develop MBA students, heads of schools (DN at ABS; CI at DBS; $\mathrm{CH}$ at EBS) are willing to encourage faculty staff with additional benefits. DN at ABS further adds that "... if HEC provides some grants every year... bind us to appoint trainers and produce graduates with competencies...support industrialization and commercialization...we will be willing to work".

Opportunity 2: Top business schools’ MBA programs as examples to encourage HEC

Participants expect the HEC to observe practices of top business schools and then support other institutions to follow-up effectively. LR at BBS notifies that "Once HEC wrote us a letter that $M B A$ and BBA students lack English skills...writing and speaking...we introduced small forums whereby students present and deliver a talk". The LR at BBS argues that it is HEC to widespread developments in MBA programs. SL at GBS says that "We fulfill all requirements of HEC...they asked for class discussion (in MBA) ...brainstorming sessions for students...we added all these things". With these understandings, we questioned about the way to motivate HEC. Participants mentioned two business schools offering finest MBA education in the country - Institute of Business Administration Karachi (IBA) and Lahore University of Management Science (LUMS). SL at BBS says that "Board of governance at institutions like LUMS and IBA have renowned multinational companies with them...they have bombastic faculty...they give fantastic graduates to corporate sector". LR at ABS says "LUMS offers quality education ...there is possibility for us to change (referring to HEC)".

Opportunity 3: Controlled admission process in business schools

Enrolment of competent students in MBA programs is one of the major issues in business schools. SL at ABS says that "Our institute do not choose students on complete competency and 
merit... admission of competitive student is a big question mark...it becomes difficult for us to make average students to work hard". DR at GBS shares his experiences of abroad and says that "... in UK students work after BBA...it is necessary for students to have work experience before admission in MBA". But many MBA students, as AP and SL at ABS, AD at GBS, and PP at EBS report, are not well-planned about their future goals when they apply for admission in MBA programs. That is the reason, perhaps, faculty members complain about students being unproductive (SL and LR at ABS; LR at BBS; LR at DBS and SL at EBS). AP at ABS and SL at BBS suggest that this issue can be solved when admission control is given to the faculty staff.

\section{Threats to Business Schools to Develop MBA Students}

\section{Threat 1: HEC as hindrance to the changes made in MBA by individual business school}

DN at ABS notifies that "Our hands are tied with HEC...it's difficult to make any change without consulting higher authorities". DN at ABS believes that private institutions are free from many hurdles of government and HEC. However, participants in private institutions share similar concerns. DR at GBS says "...we can add new topics in the subjects... we cannot make changes in the (MBA) program". SL at BBS says that they have "...controlled education system...HEC has set a curricula...(and) we follow HEC'. With these concerns, we questioned about solutions to the problems. AD at DBS mentions that their business school relies on public universities, "We adopt changes they (public universities) recommend (translated into English)", and public universities follow HEC's instructions. Thus, individual business schools are unable to make changes in MBA programs because they expect interventions of the HEC.

\section{Threat 2: Political and social pressures on business schools}

External pressures and favoritism in terms of hiring of faculty member, student politics and social influences bring some unexpected challenges for business schools (LR at ABS; SL at GBS; LR at DBS and SL at EBS). Hiring of faculty members on personal favor eliminates the competition (AD at $\mathrm{ABS}$ ) and “...it's difficult to pressure influential teacher to work" (LR at ABS). On the other hand, student having social or political influences are also reluctant to learn and cooperate (AD at DBS). These external unexpected issues restrain the efforts and interests of competitive faculty members to effectively develop students in MBA programs.

\section{Discussion of Findings}

Interviews with participants enabled this study to acquire factors that influence development of managerial knowledge, skills and experiences of MBA students in business schools. Findings show sixteen different factors, comprising of four strengths, seven weaknesses, three opportunities, and two threats. Table 3 shows factors in SWOT analysis format with total numbers and percentage of counts based on responses of participants.

In Figure 1, the third number opportunity - Controlled admission process in business schools, stands highest with $76 \%$ of counts. Thirteen participants out of eighteen notify this opportunity available at business schools in Hyderabad. The second highest factor count is in the weaknesses segment which stands 59\%. It shows that ten participants out of eighteen notify that lack of student's interests deter faculty members to develop their managerial knowledge, skills and experiences. The third highest factor count is also in weaknesses segment which stands $53 \%$. 
Nine participants have highlight the need of books, research articles and case studies on local industry to develop MBA students based on local business requirements.

Table 3: Number and Percentage of Counts of Mentioned

\begin{tabular}{|c|c|c|}
\hline $\begin{array}{l}\text { SWOT } \\
\text { Segments }\end{array}$ & Factors Explored & $\begin{array}{l}\text { Number and Percentage of } \\
\text { Participants Mentioning it }\end{array}$ \\
\hline \multirow[t]{4}{*}{ Strengths } & $\begin{array}{l}\text { 1. Initiatives and efforts of faculty members and head of } \\
\text { business school at personal level }\end{array}$ & $4(24 \%)$ \\
\hline & $\begin{array}{l}\text { 2. Contributions of fresh and foreign qualified faculty } \\
\text { members }\end{array}$ & $4(24 \%)$ \\
\hline & $\begin{array}{l}\text { 3. Role of Students with management education back- } \\
\text { ground (for example BBA) }\end{array}$ & $5(29 \%)$ \\
\hline & 4. Working students (managers and entrepreneurs) & $3(18 \%)$ \\
\hline \multirow[t]{7}{*}{ Weaknesses } & 1. Lack of faculty members' interests and capabilities & $7(41 \%)$ \\
\hline & 2. Politics in academia & $5(29 \%)$ \\
\hline & 3. Low fee structure of MBA programs & $6(35 \%)$ \\
\hline & 4. Lack of student's interests & $10(59 \%)$ \\
\hline & $\begin{array}{l}\text { 5. Shortage of local-business based literature, research } \\
\text { and case-studies }\end{array}$ & $9(53 \%)$ \\
\hline & 6. Inadequate educational background of students & $8(47 \%)$ \\
\hline & 7. Overpopulated MBA students in classrooms & $3(18 \%)$ \\
\hline \multirow[t]{3}{*}{ Opportunities } & 1. Benefits for faculty members and local managers & $7(41 \%)$ \\
\hline & $\begin{array}{l}\text { 2. Top business schools' MBA programs as examples to } \\
\text { encourage HEC }\end{array}$ & $6(35 \%)$ \\
\hline & 3. Controlled admission process in business schools & $13(76 \%)$ \\
\hline \multirow[t]{2}{*}{ Threats } & $\begin{array}{l}\text { 1. HEC as hindrance to the changes made in MBA by } \\
\text { individual business school }\end{array}$ & $5(29 \%)$ \\
\hline & 2. Political and social pressures on business schools & $7(41 \%)$ \\
\hline
\end{tabular}

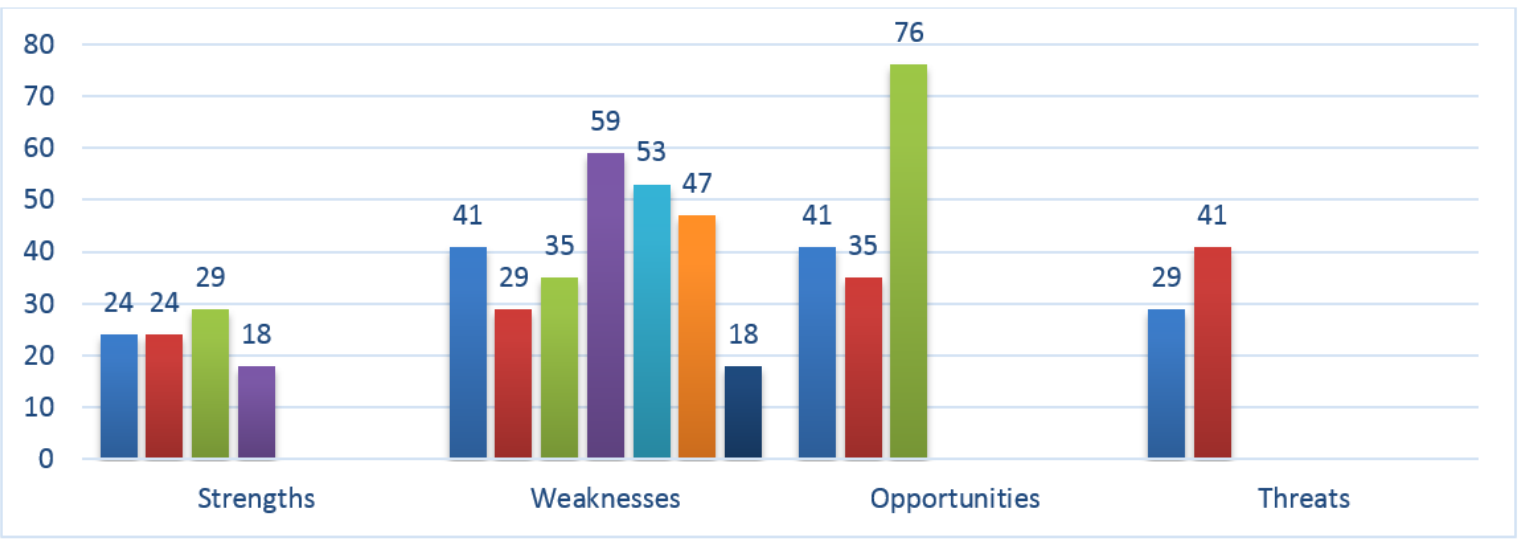

Figure 1: Comparison of SWOT factors in percentage of counts

In addition, the percentage of number of counts for the factor "inadequate educational background of students" as weakness is $47 \%$. The number of counts for "Lack of faculty members' interests and capabilities" in weaknesses, "benefits for faculty members and local managers" in opportunities, and "political and social pressures on business schools" in threats segment is same with $41 \%$. It shows that seven participants talk about major hindrances and opportunity towards development of MBA students. Moreover, the number of counts of 
remaining factors ranges from $18 \%$ to $35 \%$, which shows that three to six participants have highlight those factors.

Figure 2 illustrates SWOT factors using forcefield analysis model. The components of management development, namely, managerial knowledge, skills and experiences, are placed in the center because these components are the core focus of this study. Factors are divided on the either sides. Supporting factors are strengths and opportunities, and opposing factors are weaknesses and threats. Strengths and weaknesses are internal to the business schools, whereas opportunities and treats are external to the business schools.

According to Figure 2, there are seven factors supporting and nine factors opposing the endeavors of developing managerial knowledge, skills and experiences of MBA students in the business schools. Findings show that business schools may need more supporting factors to overcome the weaknesses and treats identified in this study. For this purpose, business schools may require support from stakeholders and higher education authorities. Collaborative efforts with external entities and policy makers could effectively improve business education programs, so that business schools could cover all three components of management development in MBA education.

Supporting Factors

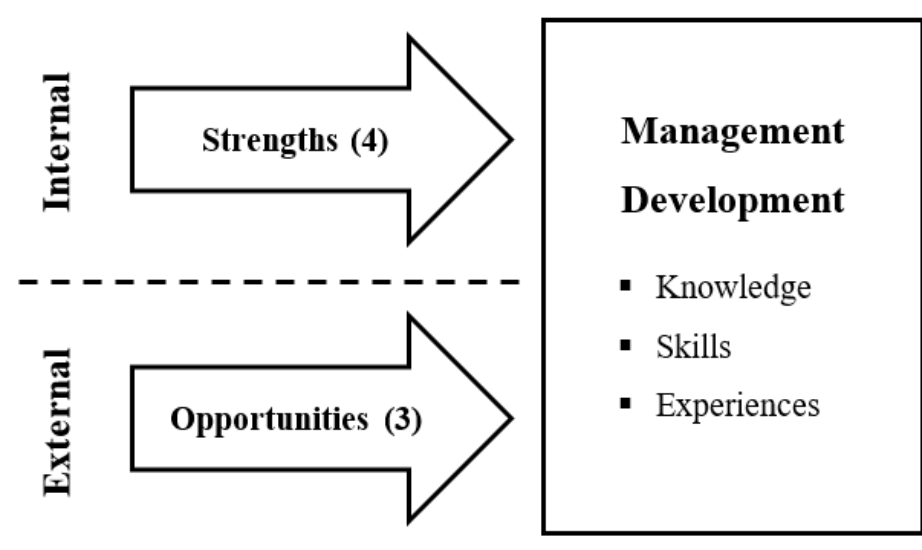

Total Factors: 7
Opposing Factors

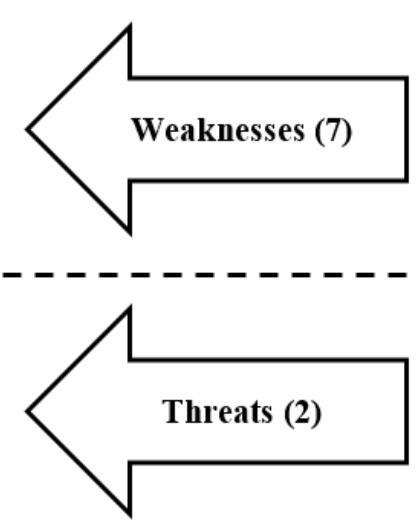

Total Factors: 9

Figure 2: Forcefield analysis model of SWOT factors

\section{Conclusion and Implications}

Noticeably, there are more number of weaknesses of business schools to develop managerial knowledge, skills and work-based learning experiences of students in MBA programs. However, business schools have some strengths and opportunities which they may utilize and improve. Findings show that most of the participants recommend business schools to control the intake of MBA students, which may help overcoming at least three weaknesses identified, namely, lack of student's interests, inadequate educational background of students, and overpopulated MBA students in classrooms. Eligibility criteria of having graduation in business administration and prior work experience could be imposed for the admission into MBA programs. In addition, the schools could require students to pass aptitude test (i.e. Graduate Record Examination), English 
language test (i.e. IELTS) and limit the number of student enrolment up to thirty in each batch. These endeavors may help to improve the quality of teaching and learning in the business schools.

The head of business schools play a major role in enhancing and maintaining the quality of teaching staff. The head of schools may offer industrial trainings to the faculty members having academic experiences only. The head of schools could also impose faculty members to publish articles, books and case-studies to overcome shortage of literature on local industry, which may also improve existing MBA curricula and enhance the relevancy towards the local businesses. These endeavors for enhancing the quality of teaching staff may increase financial burdens on business schools, for which business schools may have to revise fee structure of MBA education. Increase in fee structure could also enable business schools to offer more hands-on activities for MBA students in the school and in the industry to enhance their work-based learning experiences. Higher education authority also could help business schools in acquiring alternative sources of income through collaboration with industry and government to cover growing expenses.

To reduce political influences on academia and external pressures on business schools, we believe that radical changes through the higher education authority is needed. Higher education authority may not be able to directly deal with issues external to business schools, but the authority may help reduce its impact on business schools that could develop knowledge, skills and experiences of MBA students. Conceptual framework presented in Figure 3 recommends that higher education authority to lead the change, cooperate between business schools and stakeholders, and support business schools to effectively develop MBA students based on regional needs.

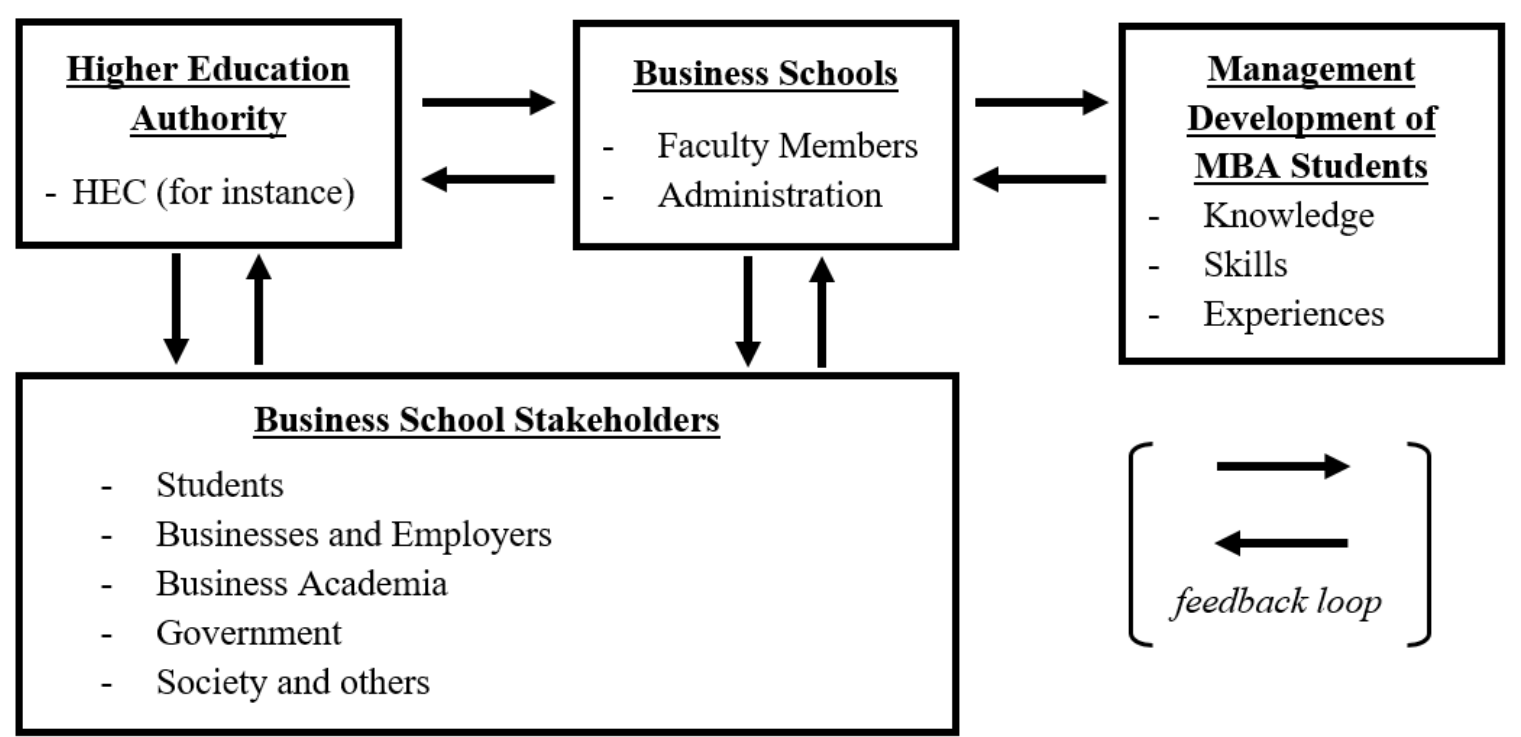

Figure 3: Conceptual framework to support management development of MBA students

Business schools in Hyderabad, Pakistan oblige and follow instructions from the Higher Education Commission (HEC). Therefore, HEC as a regulatory body and authority could pressure the change. Specifically, this study recommends higher education authority may: 1) 
Revise and establish standard MBA programs that develop management knowledge, skills and work-based learning experiences of MBA students, and impose its application in all recognized business schools in the country; 2) Begin with developmental changes in large and reputable public universities because many students, private and affiliated business schools count on them; 3) Provide necessary financial support and other resources to emergent business schools to ease their progressive efforts; 4) HEC to operate as moderator and cooperate between business schools, industry, universities, government and other stakeholders in the country to reinforce the development of managerial capital through management education; 5) Encourage faculty members to collaborate with industry and produce publications based on local business environs; and 6) Frequently update MBA programs and co-curricular activities with assistance of local and international business schools.

Last but not least, Nabi and Liñán (2011) suggest business schools in developing countries to overcome two important challenges in management education context - "help develop graduate entrepreneurs" and provide them "appropriate supportive environment" (p. 327). In addition, Raza, Murad, and Kayani (2010) recommend business schools in Pakistan to offer "culture which encourages learning of effective managerial knowledge is thought to be most relevant in creating appropriate learning climate for acquiring business and managerial knowledge" (p. 258). We second these suggestions. Although, all three components of management development, namely, managerial knowledge, skills and work-based learning experiences, are considered equally important for developing students in MBA programs, but business schools should also provide managerial learning environment and culture within the school to reinforce training programs and enhance learning experiences of MBA students.

\section{Limitations and Areas of Future Research}

This study is narrow in its scope, methodological approaches and geographical coverage. Future studies may examine factors explored based on importance of each factor with respect to the perspectives of stakeholders of business schools. In addition, developing global business capabilities of MBA students in business schools (Randolph, 2011) also remains an interesting topic in developing countries context. Future studies could also explore similar study in business schools in another city with similar characteristics, and compare and contrast the findings. Furthermore, future studies can also explore difference between performances of business schools based on collaborations with stakeholders. These types of endeavors would allow exploration of important findings that collectively would foster growth of business schools in developing countries, whilst improving their managerial capital.

\section{References}

AACSB. (2015). Business school data guide 2015. AACSB International. Retrieved from http://www.aacsb.edu/ /media/AACSB/Publications/data-trends-booklet/2015.ashx

Ali, S. (2011). Policy analysis of education in Sindh. Retrived from http://unesco.org.pk/education/documents/situationanalysis/Policy_Analysis_Sindh.pdf

Baruch, Y. (2009). To MBA or not to MBA. Career Development International, 14(4), 388-406. http://dx.doi.org/10.1108/13620430910979862

Blank, J., Clary, C., \& Nichiporuk, B. (2014). Drivers of long-term insecurity and instability in Pakistan: Urbanization. Santa Monica, CA: RAND Corporation.

Creswell, J. W. (2012). Qualitative inquiry and research design: Choosing among five approaches. Thousand Oaks, CL: SAGE. 
Cunliffe, A. L. (2014). A very short, fairly interesting and reasonably cheap book about management. Thousand Oaks, CL: SAGE.

Datar, S. M., Garvin, D. A., \& Cullen, P. G. (2011). Rethinking the MBA: Business education at a crossroads. Journal of Management Development, 30(5), 451-462. http://dx.doi.org/10.1108/02621711111132966

Fincham, R., \& Clark, T. (2009). Introduction: Can we bridge the rigour-relevance gap? Journal of Management Studies, 46(3), 510-515. http://dx.doi.org/10.1111/j.1467-6486.2009.00834.x

Gera, R. (2012). Bridging the gap in knowledge transfer between academia and practitioners. International Journal of Educational Management, 26(3), 252-273. http://dx.doi.org/10.1108/09513541211213336

Ghoshal, S. (2005). Bad management theories are destroying good management practices. Academy of Management Learning \& Education, 4(1), 75-91. http://dx.doi.org/ 10.5465/amle.2005.16132558

Harrington, D., \& Kearney, A. (2011). The business school in transition: New opportunities in management development, knowledge transfer and knowledge creation. Journal of European Industrial Training, 35(2), 116-134. http://dx.doi.org/10.1108/03090591111109334

Hommel, U., \& Thomas, H. (2014). Research on business schools: Themes, conjectures, and future directions. In A.M. Pettigrew, E. Cornuel., and U. Hommel (Eds.). The institutional development of business schools (pp. 6-35). Oxford, UK: Oxford University.

Ismail, F., Anjum, M., Mamon, A., \& Kazi, T. (2011). Trace metal contents of vegetables and fruits of hyderabad retail market. Pakistan journal of nutrition, 10(4), 365-372.

Jamil, R. (2015). Agents of American hegemony in management education: Evidence from Malaysia. The International Journal of Management Education, 13(3), 302-315. http://dx.doi.org/10.1016/j.ijme.2015.09.002

Kaleem, A. (2005). Effectiveness of IT in business education: A case of business schools in Pakistan. Pakistan Journal of Social Sciences, 3(8), 1082-1090.

Khan, A., Estrada, M. A. R., \& Yusof, Z. (2015). How terrorism affects the economic performance? The case of Pakistan. Quality \& Quantity, 50(2), 867-883. http://dx.doi.org/10.1007/s11135-015-0179-z

Khan, A., Shah, I. M., \& Azam, K. (2011). Business education in Pakistan: Growth, problems and prospects. Greener Journal of Business and Management Studies, 1(1), 1-8.

Khurana, R. (2010). From higher aims to hired hands: The social transformation of American business schools and the unfulfilled promise of management as a profession. Princeton, NJ: Princeton University.

Kieser, A., \& Leiner, L. (2009). Why the rigour-relevance gap in management research is unbridgeable. Journal of Management Studies, 46(3), 516-533. http://dx.doi.org/10.1111/j.1467-6486.2009.00831.x

Leedy, P. D., \& Ormrod, J. E. (2001). Practical research: Planning and design. Upper Saddle River, NJ: Merrill Prentice Hall.

Locke, R. R., \& Spender, J.-C. (2011). Confronting managerialism: How the business elite and their schools threw our lives out of balance. London, UK: Zed Books.

Ly, C. T. M., Vickers, M. H., \& Fernandez, S. (2015). Master of Business Administration (MBA) student outcomes in Vietnam: Graduate student insights from a qualitative study. Education + Training, 57(1), 88-107. http://dx.doi.org/10.1108/ET-08-2013-0104

Maddison, A. (2013). Economic progress and policy in developing countries. London, UK: Taylor \& Francis.

Mari, J., Shahzadi, A., \& Chachar, Q. (2011). Perception of the problems in farming community at Hyderabad Pakistan. Journal of Agricultural Technology, 7(1), 9-17.

Meyer, H. D. (2003). Between theory and experience: The dia-logical nature of managerial knowledge Implications for the preparation of education leaders. Journal of Educational Administration, 41(5), 455470. http://dx.doi.org/10.1108/09578230310489326

Miles, M. B., Huberman, A. M., \& Saldana, J. (2014). Qualitative Data Analysis: A Methods Sourcebook (3 ${ }^{\text {rd }}$ ed.). Thousand Oaks, CA: SAGE.

Mitroff, I. I., Alpaslan, C. M., \& O'Connor, E. S. (2015). Reflections: What's wrong with business schools and why they need to change. Journal of Change Management, 15(2), 85-91. http://dx.doi.org/10.1080/14697017.2015.1014643

Muff, K. (2012). Are business schools doing their job? Journal of Management Development, 31(7), 648-662. http://dx.doi.org/10.1108/02621711211243854

Muff, K., Dyllick, T., Drewell, M., North, J., Shrivastava, P., \& Haertle, J. (2013). Management education for the world: A vision for business schools serving people and the planet. Cheltenham, UK: Edward Elgar.

Mustafa, D., \& Sawas, A. (2013). Urbanisation and political change in Pakistan: Exploring the known unknowns. Third World Quarterly, 34(7), 1293-1304. http://dx.doi.org/10.1080/01436597.2013.824657 
Nabi, G., \& Liñán, F. (2011). Graduate entrepreneurship in the developing world: Intentions, education and development. Education + Training, 53(5), 325-334. http://dx.doi.org/10.1108/00400911111147668

Nonaka, I., \& Takeuchi, H. (1995). The knowledge-creating company: How Japanese companies create the dynamics of innovation. Oxford, UK: Oxford University.

Örtenblad, A., Koris, R., Farquharson, M., \& Hsu, S. W. (2013). Business school output: A conceptualisation of business school graduates. The International Journal of Management Education, 11(2), 85-92. http://dx.doi.org/10.1016/j.ijme.2013.02.001

Paton, S., Chia, R., \& Burt, G. (2014). Relevance or 'relevate'? How university business schools can add value through reflexively learning from strategic partnerships with business. Management Learning, 45(3), $267-$ 288. http://dx.doi.org/10.1177/1350507613479541

Pimpa, N. (2009). Learning problems in transnational business education and training: The case of the MBA in Thailand. International Journal of Training and Development, 13(4), 262-279. http://dx.doi.org/10.1111/j.1468-2419.2009.00331.x

Posner, B. Z. (2009). A Longitudinal study examining changes in students' leadership behavior. Journal of College Student Development, 50(5), 551-563.

Rahman, T. (1999). Language, politics and power in Pakistan: The case of Sindh and Sindhi. Ethnic Studies Report, 17(1), 1730-1848.

Randolph, W. A. (2011). Developing global business capabilities in MBA students. Journal of Management Inquiry, 20(3), 223-240. http://dx.doi.org/10.1177/1056492611401027

Raza, A., Murad, H., \& Kayani, A. (2010). Perceptions of MBA students towards learning climate for managerial knowledge: A study of business school in Lahore. Multicultural Education \& Technology Journal, 4(4), 251-260. http://dx.doi.org/10.1108/17504971011087540

Revans, R. W. (1982). What is action learning? Journal of Management Development, 1(3), 64-75. http://dx.doi.org/10.1108/eb051529

Revans, R. W. (1998). ABC of action learning. London, UK: Lemos \& Crane.

Saks, A. M., Tamkin, P., \& Lewis, P. (2011). Management training and development. International Journal of Training and Development, 15(3), 179-183. http://dx.doi.org/10.1111/j.1468-2419.2011.00381.x

Sambrook, S., \& Willmott, H. (2014). The rigor of management education and the relevance of human resource development: Natural partners or uneasy bedfellows in management practice? Management Learning, 45(1), 39-56. http://dx.doi.org/10.1177/1350507612468422

Sheikh, N. A., \& Wang, Z. (2012). Effects of corporate governance on capital structure: Empirical evidence from Pakistan. Corporate governance: The international journal of business in society, 12(5), 629-641. http://dx.doi.org/10.1108/14720701211275569

Syed, O. R., \& Omar, R. (2016). Restoring the relevance: Conceptualizing a collaboration model for business schools. International Interdisciplinary Business-Economics Advancement Journal, 1(2), 85-93.

Thomas, H., Thomas, L., \& Wilson, A. (2013). The unfulfilled promise of management education (ME): The role, value and purposes of ME. Journal of Management Development, 32(5), 460-476. http://dx.doi.org/10.1108/02621711311328255

Varela, O., Burke, M., \& Michel, N. (2013). The development of managerial skills in MBA programs: A reconsideration of learning goals and assessment procedures. Journal of Management Development, 32(4), 435-452. http://dx.doi.org/10.1108/02621711311326400

Waterval, D. G. J., Frambach, J. M., Driessen, E. W., \& Scherpbier, A. J. J. A. (2015). Copy but not paste: A literature review of crossborder curriculum partnerships. Journal of Studies in International Education, 19(1), 65-85. http://dx.doi.org/10.1177/1028315314533608

Wexley, K. N., \& Baldwin, T. T. (1986). Management development. Journal of Management, 12(2), $277-294$. http://dx.doi.org/10.1177/014920638601200209

Wright, R. P., Paroutis, S. E., \& Blettner, D. P. (2013). How useful are the strategic tools we teach in business schools? Journal of Management Studies, 50(1), 92-125. http://dx.doi.org/10.1111/j.14676486.2012.01082.x 